\title{
Digital Marketing Rumah Makan Padang Melalui Instagram Berdasarkan Social Construction of Technology
}

\author{
Dionisius Lesmana ${ }^{1}$, Gabriella Monique Valentina ${ }^{2}$ \\ ${ }^{1,2}$ Universitas Bunda Mulia, Tangerang, Indonesia
}

\begin{abstract}
ABSTRAK
Inovasi teknologi mendorong digitalisasi melalui penggunaan internet yang menyebabkan munculnya media sosial sebagai tren di Indonesia seperti Instagram. Kini, Instagram dioptimalkan sebagai media komunikasi pemasaran secara digital sebagai bentuk konstruksi sosial terhadap teknologi. Bisnis kuliner kekinian kerap ditemukan di Instagram, berbanding terbalik dengan bisnis kuliner konvensional seperti Rumah Makan Padang yang telah dikenal bahkan sebelum era digital. Namun, kini bermunculan Rumah Makan Padang berlabel kekinian yang ternyata juga memiliki akun bisnis di Instagram seperti Wira Padang Restoran. Penelitian ini bertujuan untuk mengetahui proses konstruksi sosial dari akun bisnis kuliner Rumah Makan Padang di Instagram sekaligus melihat proses digital marketing sebagai fenomena lanjutan konstruksi sosial teknologi tersebut. Penelitian ini menggunakan metode kualitatif dengan pendekatan studi kasus melalui proses wawancara mendalam. Temuan penelitian menunjukan bahwa konstruksi sosial teknologi akun Instagram Rumah Makan Padang @ wirapadangresto sebagai akun bisnis melewati negosiasi pengguna Instagram dan pemilik bisnis untuk mendapatkan dan membagikan informasi, adanya kesepakatan bahwa fitur dan layanan Instagram sebagai akun bisnis cukup memuaskan bagi kelompok sosial yang relevan sehingga Instagram sebagai akun bisnis mencapai bentuk akhir yang stabil. Konteks lebih luas terlihat pada kebiasaan pengguna dalam mengunggah konten makanan di Instagram dan tren pelaku bisnis yang membuat akun di Instagram untuk mendapatkan pengakuan digital. Aktivitas digital marketing pada Instagram terlihat pada aspek branding yang dieksekusi melalui konten, tone feeds, caption/gaya bahasa, dan hashtag. Aspek kelengkapan melalui aplikasi Campsite untuk berbagi tautan dengan fungsionalitas Instagram yang user friendly. Interaktivitas melalui relasi yang dibangun, komunikasi visual terlihat pada identitas warna untuk menciptakan brand recall, penggunaan Instagram ads dan publikasi dari influencer dan food blogger sebagai bentuk iklan yang relevan, hubungan komunitas yang dijaga melalui pendekatan yang intens dan ekslusif, dan konektivitas dengan akun media sosial lain yang dimiliki dapat membangun viralitas.
\end{abstract}

Kata kunci: pemasaran digital; Rumah Makan Padang; instagram; media sosial; konstruksi sosial teknologi

\section{Digital Marketing of Padang Restaurant through Instagram Based on Social Construction of Technology}

\begin{abstract}
Technology innovation leads to digitalization through the internet encourages the emergence of social media as a trend in Indonesia, such as Instagram. Nowadays, Instagram optimized as a digital marketing communication media as a form of social construction of technology. Present culinary business often found on Instagram, different from conventional business such as Padang Restaurant
\end{abstract}


which already known before digital era. But nowadays, the present Padang Restaurant pops up and they already have an Instagram account such as Wira Padang Restaurant. This research aims to see the social construction of technology process from Padang Restaurant's Instagram account as a form of social construction of technology and to see its digital marketing process. This research using a qualitative method with case study approach through depth interview. The result shows that Padang Restaurant's Instagram account as a social construction of technology form goes through negotiation of Instagram's users and business owner to reciprocally share information, Instagram's features and services as a business account are satisfying for the relevance social group and Instagram as a business account entering the closure and stabilization form. The broader context seen in the Instagram user's habit to upload their food on Instagram and it's been a trend for business owner to create an Instagram account to receive digital recognition. Digital marketing activities on Instagram seen in branding aspect, executed through contents, tone feeds, caption/style of language, hashtag. Completeness aspect seen through Campsite. Instagram's functionality is user friendly, interactivity seen through the relation that was built, visual communication seen at color identities for brand recall, Instagram ads and publication by influencer, food blogger as the relevant advertisement, community relations maintained through intense, exclusive approach, connectivity with another media social creates virality.

Keywords: digital marketing; Padang Restaurant; Instagram; social media; social construction of technology

\section{PENDAHULUAN}

Inovasi sektor teknologi dari masa ke masa membawa dunia masuk ke dalam era digital. Era digital lekat dengan ungkapan yang menggambarkan kemunculan media baru. Media baru merupakan sebuah media yang mengoptimalisasikan teknologi informasi dengan penggunaan jaringan internet (Rohimah, 2018). Hal tersebut juga dirasakan oleh masyarakat Indonesia seperti pada aspek komunikasi dan informasi. Indonesia sendiri berada pada posisi keenam sebagai negara dengan jumlah pengguna internet terbanyak di dunia yaitu sebanyak 132, 7 juta orang pengguna (Prameswari, 2017). Interaksi yang terfasilitasi oleh jaringan internet dan inovasi teknologi tersebut juga mendorong kehadiran media sosial. Penggunaan media sosial terlihat cukup signifikan. Hal tersebut sekaligus melahirkan sebuah fenomena yang disebut dengan budaya siber atau cyberculture (Ismanto, 2018). Cyberculture melihat suatu fenomena sosial yang meliputi jaringan internet serta wujud komunikasi jaringan lainnya. Salah satunya adalah seperti pada situs jejaring sosial (Murfianti, 2019).

Penggunaan media sosial di Indonesia memiliki signifikansi yang sangat tinggi. Hal tersebut menjadi sebuah tren untuk berbagi isu, informasi, bahkan ilmu antar penggunanya secara efisien (Fadhila \& Soesanto, 2016). Salah satu media sosial yang banyak digunakan oleh masyarakat Indonesia adalah Instagram (Nabila et al., 2020). Instagram hadir sebagai sebuah media sosial yang menarik. Instagram merupakan sebuah media sosial dimana antar pengguna dapat mengunggah dan membagikan gambar dan video (Nabila et al., 2020). Berdasarkan data yang diperoleh dari Tech Crunch pada tahun 2017, pengguna aktif Instagram bahkan telah mencapai lebih dari 700 juta orang (Anugrah, 2017).

Melalui Instagram, pengguna dapat melakukan berbagai kegiatan. Pengguna Instagram dapat mengakses informasi dan melakukan kegiatan komunikasi (Rahmadini et al., 2017). Instagram merupakan media sosial untuk berkomunikasi dengan banyak orang, mendistribusikan dan 
menerima informasi, sekaligus secara lebih dekat mengenal pengguna lainnya melalui unggahan konten berupa foto maupun video (Innova, 2016). Bagi pemilik bisnis, Instagram memiliki berbagai manfaat. Instagram bahkan dapat dioptimalkan sebagai bentuk pemasaran digital sebagai alat untuk mengembangkan dan memajukan bisnis mereka (Kusuma \& Sugandi, 2018). Dewasa ini bahkan semakin banyak yang menyadari bahwa Instagram merupakan media sosial yang sekaligus digunakan sebagai media pemasaran (Handika \& Dharma, 2018). Hal tersebut menjadi sebuah peluang yang dapat dimanfaatkan oleh para pelaku bisnis yang ingin melebarkan sayap bisnisnya ke pasar digital.

Purwanto dalam (Verawati, 2016) mengatakan bahwa orang-orang yang berbisnis tidak dapat dipisahkan dari kegiatan komunikasi dalam menjalankannya. Hal tersebut pada akhirnya menggambarkan adanya upaya komunikasi pemasaran melalui teknologi digital. Komunikasi pemasaran yang dimaksud adalah dimana masyarakat yang akan mencari informasi dengan detail dan lengkap mengenai brand dan produk untuk memenuhi keperluannya sebelum akhirnya membeli produk tersebut (Yustita, 2020). Hal tersebut mendorong pelaku bisnis untuk memanfaatkan peluang itu agar dapat berkomunikasi dengan masyarakat sebagai calon pelanggan mereka (Prasetyo et al., 2018).

Aktivitas pemasaran melalui teknologi digital atau digital marketing lebih lanjut dilihat sebagai bentuk pemasaran melalui perangkat yang terkoneksi dengan internet dengan bermacammacam strategi dan media digital untuk berinteraksi dan berkomunikasi dengan para calon konsumen menggunakan perangkat atau saluran komunikasi online yang salah satunya adalah menggunakan media sosial (Chakti, 2019). Selanjutnya, situasi tersebut sejatinya menggambarkan sebuah fenomena yang berlandaskan pemaparan mengenai social construction of technology (SCOT).

Klein dan Kleinman dalam Octavianto (2014) menyatakan social construction of technology (SCOT) atau konstruksi sosial teknologi sebagai buah pemikiran Trevor J. Pinch dan Wiebe E. Bijker pada sebuah artikel yang secara kontekstual membahas mengenai bagaimana teknologi terbentuk oleh karena suatu fenomena sosial. Dengan kata lain, konstruksi sosial membentuk teknologi itu sendiri. Pinch dan Bijker menggambarkan konstruksi sosial teknologi tersebut awalnya pada sebuah sepeda, dimana pada mulanya sepeda diciptakan dan digunakan oleh pria. Namun, karena gerakan feminisme di masa itu sedang gencar maka para kaum wanita juga ingin bersepeda sehingga muncul sepeda dengan tampilan dan spesifikasi yang disesuaikan dengan para kaum wanita (Latuheru \& Irwansyah, 2019). Berdasarkan pemaparan tersebut, maka Instagram sebagai sebuah produk teknologi tentunya hadir sebagai bentukan adanya fenomena sosial dari para penggunanya.

Kehadiran Instagram tersebut selanjutnya dapat dioptimalkan oleh para pelaku bisnis untuk berbagai kebutuhan. Melalui Instagram, bisnis restoran dapat mengunggah foto makanan yang disajikan sekaligus dapat membangun interaksi dengan para pelanggan sebelum dan atau bahkan sesudah mereka mendatangi restoran tersebut (Anggraini, 2019). Oleh karena itu, salah satu lini bisnis yang dapat ditemukan di Instagram antara lain bergerak pada industri kuliner. 
Hartman dalam Aprilia (2020) juga mengatakan bahwa media sosial dapat mendorong ketertarikan serta memberikan informasi yang terjamin apabila seseorang membutuhkan informasi mengenai menu makanan, restoran, bahkan hingga teknik memasak. Beberapa bisnis kuliner yang kerap ditemukan memiliki akun di Instagram merupakan bisnis-bisnis kuliner kekinian seperti cathering makanan sehat, gerai makan all you can eat, gerai makanan Korea, ayam geprek, mie dengan level pedas yang beragam, bahkan minuman seperti kopi dan minuman dengan topping (Rifa, 2020).

Secara singkat, bisnis kuliner yang bergerak di bidang tersebutlah yang kerap muncul, terlihat, dan ditemukan oleh para pengguna Instagram, sedangkan bisnis kuliner yang sifatnya konvensional jarang dijumpai di Instagram. Salah satu bisnis kuliner konvensional yang dimaksud dan sering dijumpai, bahkan ada dimana-mana sejak dahulu yaitu Rumah Makan Padang. Rumah Makan Padang merupakan gerai kuliner khas masakan Padang yang dapat ditemukan di berbagai daerah di Indonesia. Bahkan di ibu kota Jakarta saja dapat ditemukan dimana-mana hingga ke berbagai pelosok gang. Menu masakan yang disajikan kurang lebih memiliki ragam yang sama (Sathya, 2019). Rumah Makan Padang menyajikan hidangan kuliner khas Minangkabau (Atikah \& Setiawan, 2014).

Penamaan "Rumah Makan Padang" sendiri berasal dari penamaan kontemporer bagi restoran Minangkabau yang mulai terkenal sejak tahun 1960-an. Rumah Makan Padang yang menyajikan kuliner khas Padang tersebut kemudian dikenal dengan istilah yang lebih populer di kalangan masyarakat dengan rumah makan yang menjual menu "Nasi Padang". Nasi Padang hingga kini cukup menjadi favorit bagi masyarakat Indonesia bahkan sampai ke luar negri (Anugerah, 2019). Oleh karena itu, sebenarnya keberadaan Rumah Makan Padang sendiri sudah diketahui sejak lama oleh masyarakat Indonesia bahkan dapat ditemui di berbagai lokasi. Nasi Padang bukanlah kuliner yang sulit untuk ditemukan gerainya dan bahkan masakan yang dijual dapat dengan mudah didapatkan.

Kini, banyak pula ditemukan Rumah Makan Padang yang hadir memberikan nuansa yang lebih modern melalui menu dan suasana yang ditawarkan. Hal tersebut mendorong munculnya sebuah istilah baru, yaitu Rumah Makan Padang "kekinian” (Della, 2018). Faktanya, dapat ditemukan beberapa gerai Rumah Makan Padang kekinian tersebut telah membuat dan memiliki akun di Instagram. Namun keberadaanya mungkin belum banyak diketahui atau dilihat sebagian besar pengguna Instagram, berbanding terbalik dengan keberadaan Rumah Makan Padang secara fisik yang gerainya dapat ditemukan dimana-mana.

\section{Wira Padang Restoran}

Salah satu Rumah Makan Padang kekinian yang ada di Jakarta dan ternyata juga memiliki akun Instagram adalah Wira Padang Restoran, salah satu Rumah Makan Padang kekinian yang gerainya berada di bilangan utara Jakarta, tepatnya di daerah Kelapa Gading. Hingga saat ini, mereka sedang dalam proses untuk memperluas jaringan bisnisnya di luar Jakarta, yaitu di Bekasi dan Pulau Bali. 
Rumah Makan Padang dengan nama akun Instagram @ wirapadangresto ini memiliki jumlah followers di Instagram yang terbilang cukup banyak., yaitu mencapai 7.559 followers hingga 22 Februari 2021. Berikut ini adalah tampilan dari akun Instagram yang dimiliki dan dikelola oleh Wira Padang Restoran.

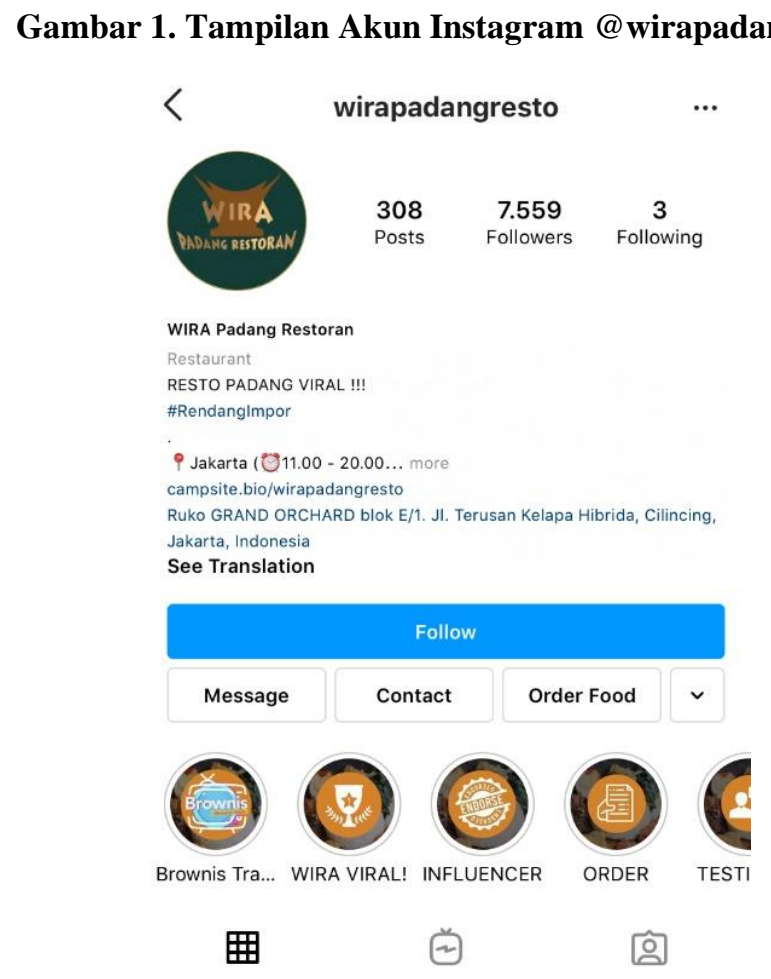

Sumber: Akun Instagram @ wirapadangresto

Mereka juga menawarkan menu kuliner Padang dalam bentuk frozen food antara lain seperti rendang, dendeng balado, gulai kikil, gulai ayam, dan bahkan sambal hijau yang dikemas dengan tradisional dan unik sehingga menjadi ciri khas, keunikan, dan bahkan unique selling point tersendiri dari Rumah Makan Padang ini. Berikut adalah tampilan kemasan frozen food yang dijual oleh Wira Padang Restoran. 


\section{Gambar 2. Kemasan Frozen Food Wira Padang Restoran}

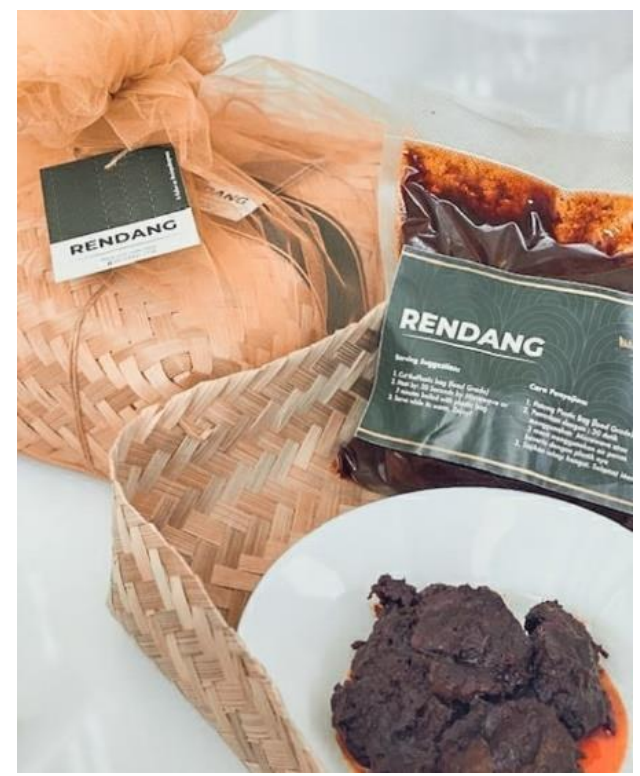

Sumber: Akun Instagram @ wirapadangresto

Berdasarkan tampilan kemasan tersebut terlihat bahwa Wira Padang Restoran berusaha memadukan konsep tradisional dengan penggunaan kemasan dari anyaman bambu yang menggunakan sistem "frozen food" yang modern dengan menggunakan plastik vacuum sealer. Selanjutnya dapat pula dilihat bagaimana mereka menyajikan salah satu konten foto menu makanan mereka melalui Instagram.

\section{Gambar 3. Konten Foto Menu Nasi Kotak Wira Padang Restoran di Instagram}

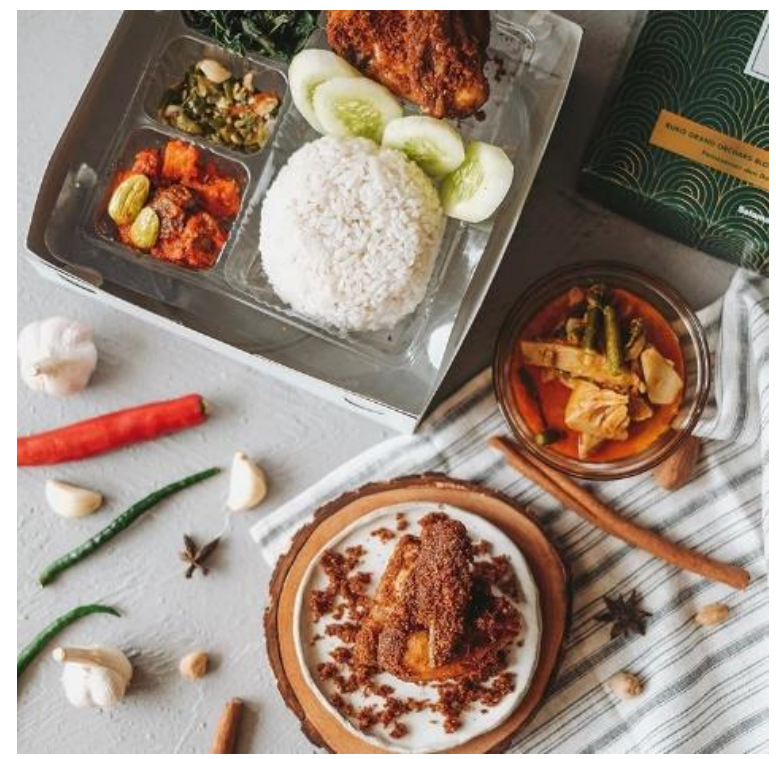

Sumber: Akun Instagram @ wirapadangresto

Konten foto tersebut sangat terlihat "Instagramable" atau diambil dengan teknik pengambilan khas foto-foto kuliner kekinian yang dapat ditemukan di Instagram. Terlihat bagaimana penyajian sebuah menu nasi kotak dengan presentasi yang tidak biasa ditemukan pada rumah- 
rumah makan Padang konvensional yang sering ditemukan selama ini. Pelanggan yang ingin merasakan kenikmatan cita rasa kuliner khas Padang tersebut juga dapat melakukan pemesanan melalui aplikasi pemesanan makanan secara online seperti Grab Food maupun memesannya melalui media e-commerce pada Tokopedia. Berdasarkan penjabaran di atas, terlihat bahwa Wira Padang Restoran mengoptimalkan penggunaan Instagram sebagai sarana komunikasi pemasaran.

Berdasarkan hal tersebut, penelitian ini perlu dilakukan untuk menelaah proses konstruksi sosial dari masyarakat, khususnya pengguna Instagram pada kemunculan akun Instagram yang digunakan oleh pelaku bisnis dalam mengelola bisnisnya. Penelitian ini mengungkapkan bagaimana Rumah Makan Padang sebagai restoran konvensional yang sudah dikenal masyarakat Indonesia bahkan sebelum era media sosial Instagram menjadi booming dan sejatinya dapat ditemui di berbagai daerah juga rupanya turut mengikuti perkembangan jaman dengan memberikan nuansa yang lebih modern dan kekinian dengan menjajaki Instagram. Penelitian ini perlu dilakukan pula khususnya bagi bidang komunikasi pemasaran untuk melihat media sosial sebagai media yang dapat digunakan untuk aktivitas pemasaran digital melalui optimalisasi penggunaan media komunikasi Instagram sebagai bentukan konstruksi sosial tersebut.

Oleh karena itu, penelitian ini bertujuan untuk mengetahui proses konstruksi sosial teknologi akun Instagram Rumah Makan Padang @ wirapadangresto sekaligus melihat aktivitas digital marketing sebagai fenomena lanjutan yang tampak setelah pembentukan kontruksi sosial Instagram akun bisnis.

\section{KERANGKA TEORETIS}

\section{Social Construction of Technology (SCOT)}

Klein dan Kleinman dalam Octavianto (2014) menyatakan bahwa teori Social Construction of Technology (SCOT) merupakan buah pemikiran Trevor J. Pinch dan Wiebe E. Bijker pada sebuah artikel yang secara kontekstual membahas mengenai bagaimana teknologi terbentuk oleh karena suatu fenomena sosial. Dengan kata lain, konstruksi sosial membentuk teknologi itu sendiri. Selanjutnya, kerangka konseptual SCOT Pinch dan Bijker tersebut terdiri atas empat konsep yang saling berhubungan (Klein \& Kleinman, 2002).

Konsep pertama yaitu interpretative flexibility (fleksibilitas interpretatif) dimana pemikiran tersebut diambil dari program empiris relativisme pada ilmu sosial dari ilmu pengetahuan. Para ahli menerapkan konsep fleksibilitas interpretatif pada suatu artefak teknologi. Artefak yang dimaksud tersebut merupakan suatu hasil dari negosiasi yang terjadi antar kelompok. Hal tersebut menunjukan adanya keterbukaan dalam desain teknologi, maka dari itu hasilnya akan berbeda, tergantung pada proses pembangunan teknologi itu (Klein \& Kleinman, 2002). Misalnya pada kajian Pinch dan Bijker mengenai konsep social construction of technology yang diawali oleh sepeda, dimana sepeda yang semula ditujukan oleh kaum pria mengalami perubahan ketika kaum wanita juga memiliki keinginan untuk bersepeda sebagai bentuk maraknya gerakan feminisme di masa itu. Kemudian, munculah sepeda dengan spesifikasi 
yang disesuaikan dengan kebutuhan wanita. Adanya perubahan konsep tersebut menunjukan bahwa penyesuaian desain sepeda adalah bentuk konstruksi dari teknologi (Latuheru \& Irwansyah, 2019). Fleksibilitas interpretatif dalam hal ini melihat bahwa interpretasi pada artefak teknologi merupakan sesuatu yang fleksibel bagi para kelompk sosial yang relevan (Octavianto, 2014).

Kedua, konsep yang relevan dengan kelompok sosial. Pinch dan Bijker dalam Klein \& Kleinman (2002) menyatakan bahwa kelompok sosial tersebut berbagi set dari pengertian dan makna, yang melekat pada suatu artefak yang spesifik. Mereka selanjutnya disebut sebagai agen yang tindakannya memberikan makna pada artefak tersebut. Pengembangan teknologi tersebut merupakan suatu proses dimana dalam beberapa kelompok, masing-masingnya mewujudkan interpretasi spesifik dari sebuah artefak, bernegosiasi atas desain dan pembentukannya, dimana kelompok sosial yang berbeda melihat dan membentuk objek yang berbeda-beda (Klein \& Kleinman, 2002). Contohnya, kelompok-kelompok tersebut dapat saja memiliki definisi berbeda dari teknologi yang ada sehingga perkembangan berlangsung hingga seluruh kelompok sampai pada sebuah kesepakatan bersama (konsensus) dimana artefak mereka bersama dapat bekerja. Desain tersebut tidak berhenti karena artefak dalam artian objektif, namun karena sekumpulan kelompok sosial yang relevan melakukan penerimaan bahwa artefak tersebut bekerja untuk mereka seperti yang disampaikan Bijker dalam Klein \& Kleinman (2002). Kelompok sosial dalam hal ini juga dapat dilihat sebagai bentuk kelompok sosial yang berjejaring (Irwanto \& Irwansyah, 2020).

Konsep ketiga yaitu closure and stabilization (penutupan atau keberakhiran dan stabilisasi). Proses desain antar kelompok mungkin saja menjadi kontroversi ketika interpretasi yang berbeda mengarah pada gambaran dari artefak yang bertentangan. Desain pun akan terus berlanjut hingga konflik dapat teratasi, selesai, dan artefak tidak lagi memberikan masalah pada kelompok sosial yang relevan. Proses antar kelompok tersebut pada akhirnya berakhir atau masuk ke dalam kondisi penutupan atau keberakhiran, tidak ada perkembangan terjadi secara lanjut, dan artefak memiliki bentuk akhir yang stabil; adanya stabilitas (Klein \& Kleinman, 2002). Pinch dan Bijker dalam Klein \& Kleinman (2002) menyajikan dua contoh mekanisme dimana dalam sebuah kasus penutupan retoris, sebuah pernyataan dibuat bahwa tidak ada masalah lanjutan yang ada dan tidak memerlukan tambahan desain. Penutupuan dengan pengulangan terjadi masalah yang belum diselesaikan didefinisikan ulang kembali sehingga hal tersebut tidak menjadi masalah kelompok sosial kembali.

Konsep keempat adalah konteks yang lebih luas. Konteks yang lebih luas dalam artian lingkungan politik dan sosiokultural yang terjadi pada pengembangan artefak (Klein \& Kleinman, 2002). Hal tersebut berhubungan dengan aspek politik, sosial, dan budaya (Latuheru \& Irwansyah, 2019). Latar belakang keadaan interaksi kelompok seperti hubungan antara satu dengan yang lain, aturan mengenai interaksi mereka, dan faktor yang bergantung pada perbedaan dalam kekuatan mereka secara garis besar tetap tidak terlihat (Klein \& Kleinman, 2002). Dalam hal ini, Baalen et al. dalam Irwanto \& Irwansyah (2020) menyatakan bahwa konteks sosial yang akan terlihat dapat berupa konteks sosio-digital. 


\section{Digital Marketing (Pemasaran Digital)}

Digital marketing (pemasaran digital) merupakan upaya pemasaran melalui perangkat yang terkoneksi dengan internet dengan bermacam-macam strategi dan media digital untuk berinteraksi dan berkomunikasi dengan para calon konsumen menggunakan perangkat atau saluran komunikasi online yang salah satunya adalah menggunakan media sosial (Chakti, 2019).

Strategi pemasaran digital merupakan upaya integrasi strategi pemasaran dengan saluran lain (Rumondang et al., 2020). Inovasi pemasaran digital tersebut dapat memberikan keuntungan bagi perusahaan, brand, atau pelaku bisnis yang menerapkannya melalui sembilan aspek. Pertama, branding sebagai media penjualan berbasis web yang dapat membentuk dan membangun image (citra) brand yang baik karena lingkup cakup, keberadaan, dan kebaruan secara konstan (Rumondang et al., 2020). Kedua, kelengkapan sebagai peluang untuk berbagi informasi melalui sebuah tautan sehingga dapat menyasar konsumen sesuai dengan target secara luas. Konsumen pun dapat melakukan pendekatan terhadap pemilik brand. Kemudian, aspek fungsionalitas sebagai situs dengan tampilan sederhana yang user friendly sehingga memudahkan pengguna dalam mendapatkan pengalaman (user experience) ketika berada pada situs tersebut.

Lalu, aspek interaktivitas mengenai bagaimana situasi yang interaktif dapat tercipta antara perusahaan atau brand dengan konsumen dalam jangka panjang. Hal tersebut memungkinkan terjadi percakapan antara keduanya sehingga menumbuhkan sebuah pengalaman yang dapat menjadi evaluasi produk. Selanjutnya, aspek komunikasi visual melalui penggunaan gambar dan video yang beraneka ragam oleh perusahaan atau brand untuk menjangkau konsumennya sekaligus menciptakan pengalaman, keterlibatan, dan jangkauan yang lebih besar atas konsumennya. Setelah itu, iklan yang relevan melalui optimalisasi iklan yang dibuat berdasarkan target dan segmen produk karena memungkinkan adanya iklan yang lebih menarik.

Kemudian. aspek hubungan komunitas yang memungkinkan adanya peluang unik antara perusahaan atau brand dengan konsumennya untuk membangun sebuah relasi atau hubungan yang dapat membangun sebuah pengalaman unik (Rumondang et al., 2020). Dan yang terakhir adalah aspek viralitas. Janosik (2005) dalam Rumondang et al. (2020) menyatakan bahwa ada relevansi dalam komunikasi viral karena adanya relasi yang saling terhubung, cepat, dan mudah pada media online untuk meningkatkan tersebarnya konten seperti pada model komunikasi WoM (Word of Mouth) atau dari mulut ke mulut.

\section{METODE PENELITIAN}

Penelitian ini merupakan penelitian kualitatif untuk memahami fenomena yang terjadi secara deskriptif dalam sebuah konteks (Moleong, 2018). Penelitian ini dilakukan dengan menggunakan pendekatan studi kasus. Pedekatan studi kasus dilakukan dengan meneliti data berupa informasi yang didapatkan secara detail pada sebuah kasus dan keadaan di sekelilingnya 
yang dapat menghubungkan ide-ide abstrak dengan kasus yang diteliti sehingga ide abstrak tersebut dapat dikaitkan dengan pengalaman hidup nyata (Neuman, 2019).

Teknik pengumpulan data dilakukan melalui wawancara mendalam untuk mendapatkan informasi secara terperinci melalui pengembangan pertanyaan berdasarkan jawaban yang disampaikan informan (Morissan, 2019). Hal tersebut dieksekusi dengan mengajukan pertanyaan kepada informan yang terlibat pada kasus dan proses yang diteliti, yaitu Erwin Prakoso Asmoro selaku pemilik dan Creative Designer dan Eric Setiabudi Asmoro selaku pemilik dan Social Media Strategist dari Wira Padang Restoran. Selanjutnya, peneliti juga mewawancarai empat orang pengguna Instagram yang berasal dari berbagai usia, jenis kelamin, dan latar belakang yang berbeda untuk melihat pernyataan yang mereka miliki sehubungan dengan penggunaan Instagram.

Teknik analisis data penelitian ini menggunakan model Miles dan Huberman dengan melakukan reduksi data, penyajian data, dan penarikan kesimpulan atau verifikasi (Yusuf, 2016). Triangulasi data akan dilakukan untuk memperoleh data yang saling berhubungan yang akan mewakili data berbeda pada suatu kejadian tertentu (Rosyada, 2020). Data primer yang diperoleh melalui wawancara tersebut kemudian akan direduksi agar dapat menyajikan data yang sesuai dengan fokus penelitian untuk kemudian akan ditarik kesimpulan dan dikaitkan serta dianalisis dengan teori dalam pembahasan dan melakukan verifikasi antar pihak-pihak yang terlibat yang membantu mendeskripsikan fenomena yang terjadi akan dilengkapi dengan data sekunder dari akun Instagram @ wirapadangresto.

\section{HASIL DAN PEMBAHASAN}

Fleksibilitas interpretatif dalam hal ini terlihat pada penggunaan akun bisnis Instagram sebagai hasil negosiasi antar kelompok yang saling membutuhkan, yaitu antara pemilik bisnis dan pengguna Instagram dengan memberikan dan menerima informasi. Kelompok pengguna Instagram menggunakan Instagram sebagai media ekspresi diri sekaligus untuk mendapatkan informasi dari akun bisnis yang diminati termasuk informasi promosi bisnis kuliner mulai dari produk yang ditawarkan, harga, lokasi, dan informasi lainnya. Wira Padang Restoran pun melihat kecenderungan para pengguna Instagram pada umumnya tersebut sebagai peluang untuk menciptakan brand awareness secara online melalui Instagram agar mengenal brand atau produk mereka. Wira Padang Restoran dan kelompok pengguna Instagram juga telah sampai pada sebuah kesepakatan bersama (konsensus) kelompok sosial yang relevan dengan melakukan penerimaan bahwa artefak Instagram tersebut bekerja untuk mereka secara keseluruhan. Mereka sudah cukup puas dengan fitur dan layanan Instagram dan dianggap tepat sebagai media sosial yang mempertemukan pemilik bisnis untuk memberikan informasi dengan pengguna Instagram yang membutuhkan informasi dari adanya sebuah akun bisnis.

Desain Instagram sebagai media sosial yang dapat mempertemukan akun pemilik bisnis dengan para pengguna Instagram yang membutuhkan informasi dari akun-akun tersebut dapat berlanjut sampai konflik dapat teratasi, selesai, dan artefak tidak lagi memberikan masalah pada kelompok sosial yang relevan. Wira Padang Restoran dan seorang informan dari 
kelompok pengguna Instagram berharap Instagram dapat memberikan informasi secara lebih detail, khususnya bagi Wira Padang Restoran berharap agar dapat memudahkan pengguna mencari bisnis kuliner sesuai lokasi. Namun hal-hal tersebut dilihat bukan merupakan sebuah masalah dalam pembentukan akun Instagram sebuah bisnis ini karena kembali lagi bahwa secara keseluruhan mereka telah puas dengan fitur dan layanan yang diberikan sehingga telah masuk ke dalam kondisi penutupan atau keberakhiran, belum ada perkembangan terjadi secara lanjut, dan akun Instagram untuk sebuah kegitatan bisnis memiliki bentuk akhir yang stabil seperti saat ini.

Konteks yang lebih luas terlihat pada kultur atau kebiasaan masyarakat pada pengembangan artefak yaitu Instagram sebagai akun bisnis. Para pengguna Instagram terbiasa untuk mengunggah konten berupa makanan khususnya yang bersifat unik yang mereka makan di Instagram sebagai upaya mengabadikan sebuah momen, wujud eksistensi diri, sekaligus upaya membagikan informasi kepada pengguna Instagram lainnya. Kemudian, terlihat pula kebiasaan pengguna Instagram yang cenderung tergoda, ingin mencoba, dan pada akhirnya membeli makanan yang diunggah oleh pengguna Instagram lainnya. Fenomena tersebut ditangkap sebagai peluang oleh para pemilik bisnis, termasuk Wira Padang Restoran untuk membuat akun bisnis di Instagram sebagai bentuk "tren" oleh para pemilik brand atau sebagai sebuah bentuk eksistensi digital bagi brand mereka. Wira Padang Restoran pada aspek sosial melalui interaksinya mengutamakan pembangunan relasi yang indikasinya terletak pada aktivitas like, comment, atau pertanyaan melalui fitur direct message sehingga terlihat pula konteks bahwa sebuah bisnis melalui media sosial tidak hanya sekedar memberikan informasi promosi dan berjualan, namun juga tetap berjalan di dalam jalur esensi media sosial itu sendiri, yaitu menciptakan sebuah relasi atau hubungan sosial.

Akun@ @irapadangresto yang juga merupakan bentuk pemasaran digital (digital marketing) dapat dilihat dari berbagai aspek. Aktivitas branding dilakukan untuk menunjukan brand image sebagai sebuah rumah makan Padang modern, kekinian, rasa bersaing dan harga terjangkau. Kekinian yang dimaksud adalah dengan desain interior restoran yang memadukan sentuhan estetik tradisional dan minimalis modern, menggunakan media sosial kekinian seperti Instagram dan TikTok yang dapat menciptakan viralitas. Uniknya, brand image mereka juga melekat pada para pegawainya yang harus memahami media sosial dan tanpa malu-malu bersedia diajak membuat konten untuk media sosial.

Aktivitas branding yang dilakukan dan terlihat pada akun @wirapadangresto, yaitu (1) Tone warna untuk desain konten feeds menyesuaikan dengan logo warna hijau emas yang memadukan budaya Padang melalui warna hijau dan warna emas yang memberikan kesan luxury dan elegan. (2) Caption menggunakan Bahasa Indonesia dan menghentikan penggunaan Bahasa Inggris agar dapat menyasar semua kalangan dengan gaya bahasa seperti obrolan antar sesama teman sehingga tidak kaku atau formal dan terkesan lebih santai. (3) Selaras dengan penjelasan di atas, oleh karena itu mereka konsisten mengunggah 3 konten di feeds dan harus mengunggah konten pada fitur story setiap harinya. Konten dirangkum dalam sebuah content plan yang menyajikan konten-konten seperti Wira Facts, Wira Quiz, dan pengenalan Wira Padang Restoran sendiri seperti konten berisi upaya restoran untuk menjaga sterilisasi alat 
makan di tengah pandemi yang intinya tidak hanya berisi konten-konten promosi saja. (4) Penggunaan tagar atau hashtag seperti \#WiraPadangResto dan \#WiraPadangViral juga digunakan untuk menunjukan kekhasan dari unggahan di Instagram mereka.

Pada aspek kelengkapan, Wira Padang Restoran menggunakan aplikasi bisnis online bernama campsite di bio untuk terhubung langsung dengan aplikasi WhatsApp mereka untuk memesan makanan, produk frozen food dan bahkan terhubung dengan media sosialTikTok mereka melalui sebuah link dari campsite tersebut. Instagram hadir sebagai media sosial berbasis aplikasi web yang user friendly dan memberikan user experience bagi pengguna dalam aspek fungsionalitas. Pada aspek interaktivitas, akun@wirapadangresto melakukan repost konten yang mention atau tag mereka pada fitur story agar menyenangkan pengguna Instagram yang mengunggah tersebut dan berupaya megucapkan terima kasih terlebih dahulu jika ada pesan yang masuk, membalas pertanyaan dengan bahasa yang sederhana, santai, dan dekat dengan pengguna Instagram sehingga terjalin interaktivitas yang baik, akrab, dan menciptakan kedekatan. Komunikasi visual dieksekusi melalui penggunaan warna hijau emerald dan emas yang merupakan identitas warna mereka yang bermakna penggabungan budaya Padang pada warna hijau dengan warna emas yang bermakna elegan dan mewah juga konsisten diterapkan pada tone feeds Instagram untuk menciptakan brand recall atau mengingatkan customer atau pengguna Instagram terhadap mereka.

Iklan yang relevan dan digunakan melalui Instagram tidak sebatas pesan promosi melalui Instagram Ads pada konten feeds, namun juga dengan publisitas melalui akun influencer/selebgram yang dapat mempengaruhi followers mereka dan food blogger yang memiliki ketertarikan di bidang kuliner agar dapat memberikan review detail, masukan, inovasi, dan tentunya melakukan publikasi pada akun mereka (Aryun et al, 2020). Hal yang menarik adalah bahwa banyak influencer/selebgram dan food blogger yang menghubungi mereka terlebih dahulu untuk melakukan kolaborasi (value to value) untuk review dan mempromosikan Wira Padang Restoran dan sebaliknya para content creator tersebut akan mendapatkan konten untuk akun mereka. Namun, memang ada beberapa akun yang dituju oleh restoran untuk publikasi, yaitu melalui akun@kulinergading, @jakartakuliner, @jktfoodies yang dinilai cocok untuk menjangkau target pasar mereka.

Wira Padang Restoran mengutamakan pendekatan yang intens, ekslusif, ramah,dalam berkomunikasi melalui Instagram sehingga untuk menciptakan hubungan komunitas tidak melulu memberikan promo, diskon, giveaway, program membership, namun juga dengan menjaga relasi itu sendiri secara online melalui Instagram. Viralitas terlihat pada relevansi yang saling terhubung, cepat, dan mudah pada media online untuk meningkatkan tersebarnya konten. Wira Padang Restoran yang menjual nasi Padang menggunakan mobil BMW dan Mercy dan melakukan aktivitas menyiarkan langsung kegiatan tersebut menggunakan fitur live melalui akun Instagram mereka mendorong massa hadir dan mengunggah hal tersebut yang tidak hanya di Instagram, namun juga di media sosial TikTok dan menjadi viral. Mereka pun diundang ke beberapa program acara televisi, semakin viral, dan mendorong lebih banyak pengunjung datang ke gerainya dan tentunya juga berkunjung ke media sosial yang dimiliki, maupun melakukan pembelian. 
Oleh karena itu, peneliti sekaligus dapat menjabarkan urgensi penggunaan Instagram untuk kegiatan bisnis secara ringkas melalui tabel berikut ini.

Tabel 1. Urgensi Penggunaan Instagram Untuk Kegiatan Bisnis

\begin{tabular}{ll}
\hline No. & Urgensi Penggunaan Instagram Untuk Kegiatan Bisnis \\
\hline 1. & Sebuah brand yang hadir dengan label "kekinian" tentu sebaiknya menggunakan \\
media sosial yang bersifat kekinian pula seperti Instagram.
\end{tabular}

5. Meskipun tujuan utama setiap bisnis adalah pemasaran, penjualan, dan keuntungan (profit), namun mereka yang masuk ke media sosial (Instagram) harus menyadari esensi dari media sosial itu sendiri sebagai media yang tidak hanya digunakan untuk menyampaikan informasi promosi yang sifatnya hard selling atau "berjualan", namun juga harus mampu membangun relasi sosial dan komunikasi dengan para pengguna.

6. Upaya membangun hubungan komunitas dalam digital marketing tidak hanya melalui program membership, mengadakan giveaway, dan memberikan diskon, namun juga dengan membangun relasi sosial dengan para pelanggan yang dapat dilakukan melalui Instagram sebagai media komunikasi.

7. Iklan yang relevan dapat dieksekusi tidak hanya menggunakan fitur Instagram Ads, namun juga dapat melalui aktivitas publisitas pada Instagram melalui influencer, selebgram, dan food blogger.

8. Era media sosial sekarang menunjukan sebuah era kolaborasi antara brand dengan para content creator (influencer, selebgram, dan food blogger) di Instagram, dimana para content creator dapat melakukan pendekatan kepada brand untuk membuat konten dan sebaliknya brand mendapatkan konten dari mereka (value to value).

9. Viralitas dalam digital marketing tidak melulu diciptakan oleh brand tersebut, namun di era new media dimana pengguna media sosial dapat menjadi audiens yang "aktif" sehingga mereka dapat meliput, mengunggah, dan menyebabkan viralitas sebuah brand seperti yang dialami oleh Wira Padang Restoran.

10. Viralitas tersebut dapat terjadi melalui konektivitas antar media sosial yang dimiliki sebuah brand, konten yang semula diunggah di Instagram kemudian viral di TikTok dan mendorong pengguna TikTok mengunjungi akun di Instagram seperti pada kasus Wira Padang Restoran yang bahkan juga menjadi viral di media televisi karena diundang ke beberapa program acara. 
11. Aktivitas branding pada digital marketing sebagai upaya menanamkan brand image juga terlihat pada aspek komunikasi visual dimana penggunaan identitas warna perusahaan, desain, dan tampilan pada akun Instagram terlihat.

Sumber: Data Olahan Peneliti, 2021

\section{SIMPULAN}

Penggunaan Instagram sebagai optimalisasi media sosial untuk kegiatan digital marketing diawali dari proses konstruksi sosial akun@wirapadangresto melalui empat konsep yang saling berhubungan. Fleksibilitas interpretatif terlihat pada negosiasi antara pemilik bisnis dengan pengguna Instagram yang dapat saling memberikan dan menerima informasi melalui akun bisnis. Konsep tersebut menjadi relevan bagi pihak yang terlibat karena mereka sepakat bahwa penggunaan fitur dan layanan Instagram membantu aktivitas pengiriman dan penerimaan informasi. Meskipun terdapat ekspektasi perkembangan fitur Instagram, namun hal tersebut bukan sebuah masalah karena kepuasan berbagai pihak sehingga Instagram untuk akun bisnis memiliki bentuk akhir yang stabil. Konteks yang lebih luas pada kultur atau kebiasaan pengguna Instagram untuk mengunggah konten makanan yang dapat mempengaruhi pengguna Instagram lainnya sehingga menjadi tren bagi pemilik bisnis termasuk Wira Padang Restoran untuk membuat akun Instagram mereka. Penggunaan media sosial untuk kegiatan digital marketing harus mengedepankan esensi Instagram sebagai media sosial dimana relasi antar brand dan pengguna menjadi penting selain hanya memberikan informasi bersifat promosi.

Selanjutnya, aktivitas digital marketing yang terlihat pada akun@wirapadangresto dapat dilihat melalui aktivitas branding melalui konten, tone feeds, caption/gaya bahasa, dan hashtag. Aspek kelengkapan dioptimalisasikan menggunakan campsite berupa tautan untuk menghubungkan dengan contact WhatsApp maupun media sosial lainnya dengan fungsionalitas Instagram yang user friendly. Interaktivitas dieksekusi dengan membangun relasi dengan para pengguna dimana aspek komunikasi visual diperlihatkan melalui warna pada tone feeds untuk menciptakan brand recall. Selain menggunakan Instagram Ads, mereka menggunakan publisitas dari para influencer/selebgram dan food blogger. Pendekatan yang intens, ekslusif, dan penggunaan gaya bahasa yang ramah terhadap pengguna Instagram dilakukan sebagai upaya menjaga hubungan komunitas. Viralitas melalui Instagram menunjukan adanya konektivitas dengan media sosial lainnya.

\section{DAFTAR PUSTAKA}

Anggraini, A. (2019, 11 Februari). Tips Marketing Restoran dengan Instagram.

Diperoleh dari website Nibble: https://www.nibble.id/blog/tips-marketing-restoraninstagram/

Anugerah, P. (2019, 29 November). Nasi Padang: Sejarah, Kalori, dan Semua Hal

yang Perlu Anda Ketahui. Diperoleh dari website BBC: https://www.bbc.com/indonesia/majalah-50541428

Anugrah, N. (2017, 20 Juli). Instagram Business Profile: Hal-hal yang Perlu Kamu 
Ketahui. Diperoleh dari website File Magz: https://www.filemagz.com/instagrambusiness-profile-hal-hal-yang-perlu-kamu-ketahui/

Aprilia, M.P. (2020). Pencarian Informasi Oleh Foodie Pada Foto Makanan Di Instagram. Jurnal Komunikasi Nusantara 2(1), 56-66. https://doi.org/10.33366/jkn.v2i1.40

Aryun, A., Nugraha, D. D., Di Karachi, L., Ruswan, M., \& Abdurrahman, N. (2020). Pengaruh Paparan Iklan Terhadap Brand Awareness Serta Keinginan untuk Memainkan Game AoV. COMMENTATE: Journal of Communication Management, 1(1), 95-108.

Atikah, N. S. \& Setiawan, B. (2014). Analisis Kinerja Penyelenggaraan Makanan Dan Tingkat Kepuasan Konsumen Restoran Khas Padang di Bogor. Jurnal Gizi Dan Pangan 9(1), 59-64. Diperoleh dari https://garuda.ristekbrin.go.id/documents/detail/1313130

Chakti, A. G. (2019). The Book of Digital Marketing. Makassar: Celebes Media Perkasa.

Della. (2018, 27 September). 5 Restoran Padang dengan Tampilan Kekinian di Jakarta. Diperoleh dari website Qraved: https://www.qraved.com/journal/editorspick/5-restoran-padang-dengan-tampilan-kekinian-di-jakarta

Fadhila, N \& Soesanto, H. (2016). Studi Tentang Social Media Marketing Dan Brand Awareness, Word Of Mouth Terhadap Minat Beli Produk Mommilk (Studi Pada Pengguna Instagram, Mahasiswa Universitas Diponegoro). Diponegroro Journal of $\begin{array}{llll}\text { Management } & 5(2), & \text { Diperoleh }\end{array}$ https://garuda.ristekbrin.go.id/documents/detail/1446321

Handika, M. R. \& Dharma, G. S. (2018). Strategi Pemasaran Bisnis Kuliner Menggunakan Influencer Melalui Media Sosial Instagram. Jurnal Manajemen Bisnis 15(2), 192-203. https://doi.org/10.38043/jmb.v15i2.601

Innova, E. I. (2016). Motif Dan Kepuasan Pengguna Instagram di Komunitas Instameet Indonesia. Jurnal E-Komunikasi 4(2), 1-12. Diperoleh dari https://garuda.ristekbrin.go.id/documents/detail/1246044

Irwanto \& Irwansyah. (2020). Pendekatan Social Construction of Technology untuk Teknologi Pendidikan di Indonesia. Jurnal Media Komunikasi FPIPS 19 (1), 28-41. : http://dx.doi.org/10.23887/mkfis.v19i1.24184

Ismanto, I. (2018) Budaya Selfie Masyarakat Urban Kajian Estetika Fotografi, Cyber Culture, Dan Semiotika Visual. Jurnal Rekam 14(1), 67-76. Diperoleh dari https://garuda.ristekbrin.go.id/documents/detail/1889288

Klein, H. K. \& Kleinman, D. L. (2002). The Social Construction of Technology: Structural Considerations. Jurnal Science, Technology, \& Human Values 27(1), 28-52. https://doi.org/10.1177\%2F016224390202700102

Kusuma, D. F. \& Sugandi, M. S. (2018). Strategi Pemanfaatan Instagram Sebagai Media Komunikasi Pemasaran Digital Yang Dilakukan Oleh Dino Donuts. Jurnal Manajemen Komunikasi 3 (1), 18-33. https://doi.org/10.24198/jmk.v3i1.12963

Latuheru, M N. \& Irwansyah. (2019). Aplikasi Traveloka Sebagai Bentuk Konstruksi Sosial Dalam Dunia Siber. Jurnal Kajian Media 3 (2), 79-88. http://dx.doi.org/10.25139/jkm.v3i2.1013

Moleong, L. J. (2018). Metodologi Penelitian Kualitatif. (Edisi Revisi, Cetakan 38). Bandung: PT Remaja Rosdakarya.

Morissan. (2019). Riset Kualitatif. (Edisi 1, Cetakan 1). Jakarta: Prenada Media.

Murfianti, F. (2019). Meme Di Era Digital Dan Budaya Siber. Acintya Jurnal Penelitian Seni Budaya 11(1), 42-50. https://doi.org/10.33153/acy.v11i1.2613

Nabila, D. et al. (2020). Peradaban Media Sosial di Era Industri 4.0. Malang: Prodi 
Ilmu Komunikasi Universitas Muhammadiyah Malang \& Inteligensia Media (Intrans Publishing Group).

Neuman, W. L. (2019). Metodologi Penelitian Sosial: Pendekatan Kualitatif dan Kuantitatif

(Edisi 7, Cetakan 1). Jakarta: PT Indeks.

Octavianto, A. (2014). Strukturasi Giddens dan Social Construction of Technology (SCoT)

Sebagai Pisau Analisis Alternatif Penelitian Sosial Atas Teknologi Media

Baru. Ultimacomm: Jurnal Ilmu Komunikasi, 6(2), 41-57.

https://doi.org/https://doi.org/10.31937/ultimacomm.v6i2.417

Prameswari, G.D. (2017, 22 Februari). Empat Pengaruh Digitalisasi dalam "Public

Relations". Diperoleh dari website Daily Social: https://dailysocial.id/post/empatpengaruh-digitalisasi-dalam-public-relations

Prasetyo, B. et al. (2018). Komunikasi Pemasaran Terpadu (Pendekatan Tradisional

Hingga Era Media Baru. Malang: UB Press.

Rahmadini. et al. (2017). Hubungan Motivasi Belanja Online Fashion Dengan Akses

Informasi Instagram. Shaut al-Maktabah Jurnal Perpustakaan, Arsip dan Dokumentasi 8(2), 205-218. https://doi.org/10.15548/shaut.v9i2.119

Rifa. (2020, 3 Juni). 7+ Ide Bisnis Makanan di Instagram yang Hits \& Kekinian.

Diperoleh dari website Cerita Pengusaha: https://www.ceritapengusaha.com/bisnismakanan-di-instagram/

Rohimah, A. (2018). Era Digitalisasi Media Online Dalam Gugurnya Pasar Ritel

Konvensional. Kanal (Jurnal Ilmu Komunikasi $6 \quad$ (2), 91-100. https://doi.org/10.21070/kanal.v6i2.1931

Rosyada, D. (2020). Penelitian Kualitatif Untuk Ilmu Pendidikan. (Edisi 1, Cetakan 1). Jakarta: Prenada Media.

Rumondang, A. et al. (2020). Pemasaran Digital dan Perilaku Konsumen. Medan: Yayasan Kita Menulis.

Sathya, A. (2019, 26 November). 7 Fakta Unik Seputar Rumah Makan Padang di

Indonesia. Diperoleh dari website Pegi Pegi: https://www.pegipegi.com/travel/7-faktaunik-seputar-rumah-makan-padang-di-indonesia/

Verawati, N. (2016). Pergeseran Pemanfaatan Instagram sebagai Media Bisnis Online (Studi Kasus Pada Akun @Schonehazzle).Kom \& Realitas Sosial Jurnal Ilmu Komunikasi 12(2), 12-25. Diperoleh dari https://garuda.ristekbrin.go.id/documents/detail/461008

Yustita, A. D. (2020). Komunikasi Pemasaran Antimo Anak di Media Sosial. COMMENTATE: Journal of Communication Management, 1(2), 208-221.

Yusuf, A. M. (2016). Metode Penelitian: Kuantitatif, Kualitatif, dan Penelitian Gabungan. (Edisi 1, Cetakan 4). Jakarta: Prenada Media. 